DOI: https://doi.org/10.24127/ajpm.v10i3.3711

\title{
ANALISIS MOTIVASI BELAJAR SISWA SMP DALAM PEMBELAJARAN MATEMATIKA DI ERA COVID-19
}

\author{
Budi Murtiyasa ${ }^{1}$, Aisiyah Dewi Amini2* \\ 1,2* Pendidikan Matematika, Universitas Muhammadiyah Surakarta, Indonesia \\ ${ }^{*}$ Corresponding author. Universitas Muhammadiyah Surakarta, 57162, Surakarta, Indonesia. \\ E-mail: $\quad$ budi.murtiyasa@ums.ac.id ${ }^{1)}$ \\ $\underline{\text { aminidewi05@gmail.com }}^{2 *)}$
}

Received 08 May 2021; Received in revised form 09 September 2021; Accepted 25 September 2021

\begin{abstract}
Abstrak
Dalam pembelajaran matematika di masa pandemi sebagian besar siswa mengalami kesulitan belajar yang mempengaruhi kondisi mental, terutama motivasi dalam diri siswa. Penelitian ini bertujuan untuk mendiskripsikan motivasi belajar siswa di Sekolah Menengah Pertama (SMP) dalam pembelajaran matematika. Jenis penelitian ini merupakan penelitian deskriptif. Subjek penelitian ini adalah siswa kelas IX SMP Negeri I Grogol di Sukoharjo yang berjumlah 60 orang serta objeknya adalah motivasi belajar. Teknik pengumpulan data berupa angket. Teknik analisis data menggunakan persentase dan rata-rata skor. Hasil penelitian menunjukkan bahwa rata-rata dari enam indikator motivasi belajar adalah berkategori baik diantaranya tujuan orientasi intrinsik rata-rata sebesar 3,70, tujuan orientasi ekstrinsik rata-ratanya sebesar 3,32, nilai tugas rata-ratanya 3,77, kontrol kepercayaan untuk pembelajaran rataratanya 3,70, kepercayaan diri rata-ratanya 3,78, dan indikator tingkat kecemasan didapatkan rata-rata sebesar 3,99. Dari hasil enam indikator didapatkan rata-rata keseluruhan yaitu 3,71 yang berkategori baik, yang artinya siswa SMP Negeri 1 Grogol menunjukkan bahwa motivasi belajar dalam pembelajaran matematika di era covid-19 yang mengacu pada enam indikator yang sudah ditetapkan adalah baik.
\end{abstract}

Kata kunci: Covid-19; pembelajaran; motivasi belajar.

\begin{abstract}
In learning mathematics during the pandemic, most of the student experienced learning difficulties which affected mental conditions, especially motivation in students. This study aims to describe junior high school's student's learning motivation in mathematic. This research is descriptive study. The subjects of this study were students from 9th grade of SMP Negeri I Grogol in Sukoharjo which can be measured by 60 people and the object of this research is learning motivation. The technique of activating data is in the form of a questionnaire. The data analysis technique used proportion and average score. The results showed that the average of the six indicators of learning motivation was categorized as good under an average intrinsic orientation of 3.70, the average extrinsic orientation objective was 3.32, the average task value was 3.77, control confidence. for learning an average of 3.70, an average self-confidence of 3.78, and an average reduction level indicator of 3.99. From the results of the six indicators, the total average is 3.71 which is categorized as good, which means that students of SMP Negeri 1 Grogol show that learning motivation in learning mathematics in the Covid-19 era which refers to the six predetermined indicators is good.
\end{abstract}

Keywords: Covid-19; learning ; learning motivation.

This is an open access article under the Creative Commons Attribution 4.0 International License

\section{PENDAHULUAN}

Matematika merupakan ilmu dalam setiap jenjang pendidikan baik dari sekolah dasar sampai ke perguruan tinggi. Dalam seluruh segi kehidupan manusia matematika memasuki dari 
segi paling sederhana sampai yang paling rumit. Matematika berhubungan dengan didasarkan pada penalaran deduktif meskipun pada manusia pengalam pertama dalam matematika bersifat induktif. Secara sederhana dapat diuraikan bahwa sistem deduktif melibatkan beberapa hal diantaranya adalah: 1) seperangkat istilah primitif yang tidak terdefinisi; 2) defenisi perubahan dari istilah yang tidak ditentukan; 3) aksioma atau postulat; 4) teorema dan buktinya (Antakov, 2015). Matematika perlu diberikan kepada siswa untuk membekali dalam kemampuan berpikir logis, analitis, sistematis, kritis, kreatif, dan kemampuan bekerja sama. Guru harus sadar akan perannya dalam memotivasi siswa dan membimbing siswa dalam pembelajaran matematika.

Motivasi merupakan kondisi psikologis dalam diri seseorang yang didorong oleh kemauan kuat dan menghadirkan perasaan senang dalam melakukan suatu tindakan untuk mencapai suatu tujuan tertentu. Diri seseorang yang berdasarkan emosi yang relevan dan motivasi yang hadir dari luar ketika ada yang mampu menyentuh psikologi seseorang baik dari tutur kata maupun tindakan. Motivasi memiliki peran yang sangat penting dalam kegiatan belajar mengajar baik bagi guru maupun siswa (Arianti, 2018)

Motivasi belajar sangat mempengaruhi psikis siswa yang bersifat nonpengetahuan. Siswa tidak akan mudah menyerah demi mendapatkan prestasi belajar yang memuaskan merupakan ciri dari motivasi belajar siswa yang sangat tinggi(Et, 2017)Secara umum terdapat dua faktor motivasi belajar yaitu faktor dalam diri siswa (internal) dan faktor dari luar diri siswa (eksternal). Faktor dalam diri siswa diantaranya adalah: 1) kesehatan fisik dan mental; 2) bakat; 3) minat; 4) konsentrasi; 5) kepercayaan diri; dan 6) komitmen, sedangkan faktor dari luar diri siswa diantaranya adalah: 1) rangsangan; 2) penguatan; 3) lingkungan sekolah; 4) lingkungan keluarga; 5) pertemanan; 6) kondisi masyarakat; 7) fasilitas belajar; 8) suasana belajar; dan 9) waktu belajar (Rismawati \& Khairiati, 2020)

Di era pandemi covid-19 implementasi pembelajaran matematika cukup menyulitkan siswa dan guru. Penurunan kualitas belajar pada peserta didik merupakan dampak dari pandemi.

Pada pembelajaran online, peserta didik menjadi kurang aktif dalam menyampaikan aspirasi dan pemikirannya, sehingga menyebabkan pembelajaran yang menjenuhkan. Seorang siswa yang mengalami kejenuhan dalam belajar akan mempengaruhi kemajuan dalam berpikir dan berinteraksi. Oleh karena itu, perlu adanya dorongan untuk menggerakkan siswa agar bersemangat dalam proses pembelajaran. Semangat belajar terutama dalam pembelajaran matematika dapat dimiliki dengan meningkatkan motivasi belajar. Motivasi belajar merupakan penggerak dan pendorong seseorang untuk lebih tertarik kepada belajar secara terusmenerus. Motivasi yang rendah akan mempengaruhi keberhasilan dalam belajar sehingga akan merendahkan hasil belajar pada siswa.

Terdapat penelitian yang menyebutkan bahwa motivasi belajar siswa yang rendah dapat memberikan pengaruh pada kemandirian belajar siswa selama pelaksanaan pembelajaran online (Nisa, 2021). Oleh sebab itu, perlu dilakukan penelitian untuk menganalisis motivasi belajar siswa smp dalam pembelajaran matematika di era covid-19. Selain itu, kondisi pandemi yang terus meningkat 
menyebabkan siswa mengalami kejenuhan atau kurangnya motivasi belajar terutama dalam belajar matematika.

Penelitian yang dilakukan ini dapat memberikan gambaran tentang motivasi belajar siswa di era covid-19 ini terutama dalam pembelajaran matematika. Kondisi siswa di era pandemi yang mengalami kesulitan belajar sangat mempengaruhi kondisi mental mereka. Hal inilah yang membedakan dari penelitian sebelumnya dimana kondisi pandemi sangat mempengaruhi motivasi belajar dalam pembelajaran matematika.

\section{METODE PENELITIAN}

Penelitian ini merupakan penelitian deskripstif. Tahapan dalam penelitian ini memuat beberapa hal yaitu perumusan masalah, pencarian data, analisis data, dan penyimpulan. Subyek penelitian ini adalah siswa Kelas IX SMP Negeri 1 Grogol. Pengambilan data dilaksanakkan pada tanggal 24 Desember 2020 dengan menggunakan google forms. Penelitian ini hanya menggunakan dua kelas yaitu kelas IX A dan IX B. Jumlah dari kedua kelas tersebut 64 siswa namun ketika penelitian hanya 60 siswa yang mengisi google forms yang terdiri dari 30 siswa kelas IX A dan 30 siswa kelas IX B. Angket yang diisi siswa diberi batasan selama 1x24 jam.

Data diperoleh dari hasil angket motivasi belajar yang berisi beberapa pernyataan yang terbagi dalam beberapa indikator. Indikator motivasi belajar dapat diklasifikasikan sebagai berikut: 1) tujuan orientasi intrinsi; 2) tujuan orientasi ekstrinsik; 3) nilai tugas; 4) kontrol kepercayaan untuk pembelajaran; 5) kepercayaan diri, dan 6) kecemasan saat tes (Fendiyanto, 2020). Sumber data dalam penelitian ini diperoleh dari siswa, guru, jurnal, dan buku-buku pendukung data dasar.

Teknik pengumpulan data meliputi angket, wawancara, dan dokumentasi. Angket dibuat secara tertulis dan tercetak kemudian diujikan langsung kepada responden untuk dijawab secara tertulis. Dalam proses penelitian, angket motivasi belajar dibagikan kepada siswa kelas IX A dan IX C . Instrumen lembar dalam penelitian ini menggunakan angket yang telah terdapat pilihan jawaban atau angket tertutup. Angket dalam penelitian ini terdiri dari beberapa pernyataan dan setiap pernyataan terdapat opsi jawaban yang menggunakan Skala Likert. Responden dapat memilih dengan tanda centang (V). Skala dibagikan dengan beberapa skor diantaranya 5 (sangat setuju), 4 (setuju), 3 (ragu-ragu), 2 (tidak setuju), 1 (sangat tidak setuju). Wawancara digunakan untuk mengumpulkan informasi tambahan terkait dengan penyebaran angket yang telah dilakukan dan dokumentasi terdiri dari foto-foto proses penelitian, hasil uji angket, dan hasil wawancara.

Angket motivasi belajar divalidasi oleh dosen pembimbing dan diujicobakan kepada 30 siswa SMP Negeri 1 Grogol. Sebelumnya dilakukan pembagian angket kepada responden untuk menguji kualitas data. Uji kualitas data diperoleh dari hasil angket penelitian kemudian diukur dari uji validitas dan uji reliabilitas. Pengujian validitas dilakukan untuk mengkorelasikan masing-masing dari skor item dan skor total dengan Product Momen Pearson. Jumlah sampel yang digunakan 30 dengan taraf signifikansi $5 \%$ pada distribusi nilai $r_{\text {tabel }}$ statistik. Sehingga diperoleh $r$ tabel $=0,296$. Uji reliabilitas yang digunakan dalam penelitian adalah Cronbach's alpha 
dengan metode pengambilan keputusan dengan batasan 0,6. Berdasarkan hasil analisis uji coba reliabilitas lembar kuisioner angket motivasi belajar matematika di era covid-19 diperoleh nilai Cronbach's Alpha diatas 0,8. Data yang diperoleh dari responden kemudian dianalisis dengan menghitung persentase dan rata-rata skor.

Teknik analisis data dalam penelitian ini dilakukan dengan melakukan tiga kegiatan, yaitu mereduksi data, menyajikan data, dan menarik kesimpulan. Reduksi data bertujuan untuk menyederhanakan pemahaman data yang telah dikumpulkan dari hasil angket dan wawancara siswa sehingga data yang dikurangi memberikan gambaran yang lebih rinci. Penyajian data adalah untuk merepresentasikan data yang diperoleh dengan menggambarkan hasil angket siswa. Kesimpulan adalah tahap akhir dalam proses penelitian untuk menarik kesimpulan tentang hasil angket siswa yang telah dianalisis.

\section{HASIL DAN PEMBAHASAN}

Berdasarkan penelitian yang sudah dilakukan, diperoleh data dari angket motivasi belajar siswa. Indikasi dalam indikator persepsi siswa tentang tujuan orientasi intrinsik menunjukkan baik bahwa siswa menginginkan ada materi pembelajaran yang dikreasikan oleh guru dan bahan pengajaran yang menumbuhkan kreatifitas. Kriteria baik dalam indikator yang kedua persepsi siswa tentang tujuan orientasi ekstrinsik mengindikasikan bahwa siswa dalam belajar daring memerlukan kondisi lingkungan dan keluarga yang mendukung. Indikator yang ketiga nilai tugas menunjukkan indikasi yang baik dimana siswa mampu memahami isi materi pembelajaran yang disampaikan guru secara daring. Indikasi dalam indikator kontrol kepercayaan untuk pembelajaran menunjukkan kriteria baik. Hal ini dapat diketahui bahwa siswa siswa belajar cukup keras untuk meraih nilai matematika yang tinggi. Indikator terakhir kepercayaan diri menunjukkan kriteria baik bahwa siswa mampu mengurangi kecemasan terutama saat menghadapi soal matematika yang diberikan guru dalam pembelajaran daring. Hal ini dapat dilihat dari penjelasan Tabel 2.

Tabel 2. Hasil analisis motivasi belajar siswa dalam pembelajaran matematika

\begin{tabular}{clcc}
\hline No & \multicolumn{1}{c}{ Indikator } & Mean & Kriteria \\
\hline 1 & $\begin{array}{l}\text { Persepsi siswa } \\
\text { tentang tujuan } \\
\text { orientasi intrinsik }\end{array}$ & 3.7 & Baik \\
2 & $\begin{array}{l}\text { Persepsi siswa } \\
\text { tentang tujuan } \\
\text { orientasi ekstrinsik }\end{array}$ & 3.32 & Baik \\
3 & Nilai tugas & 3.77 & Baik \\
4 & $\begin{array}{l}\text { Kontrol kepercayaan } \\
\text { untuk pembelajaran }\end{array}$ & 3.7 & Baik \\
5 & Kepercayaan diri & 3.78 & Baik \\
6 & Kecemasan saat tes & 3.98 & Baik \\
\hline Rata-rata Akumulasi & 3.71 & Baik \\
\hline
\end{tabular}

Siswa yang semangat belajar tinggi dipicu dari motivasi yang dibangun dari kesadaran diri untuk menggali kemampuan dalam melaksanakan pembelajaran online. Motivasi belajar yang baik dapat dilihat dari salah satu indikator yaitu kepercayaan diri. Kepercayaan diri merupakan sesesorang yang yakin dapat menanggulangi suatu masalah dan mampu menyenangkan orang lain dengan memberikan sesuatu yang terbaik (Nurfajriyanti \& Pradipta, 2021). Dari tabel 2 menunjukkan beberapa aspek dalam kepercayaan diri siswa menghadapi pembelajaran matematika di era covid diantaranya adalah 1) siswa kesulitan mengerjakan tugas online dengan waktu pengumpulan yang kurang memperoleh 
skor sebesar 3,85 termasuk berkategori baik. Tugas yang diberikan guru saat pembelajaran online memberikan stimulasi khusus kepada siswa untuk membangkitkan kepercayaan diri agar maksimal dalam memahami materi yang diajarkan. 2) siswa tidak mampu memahami semua topik dalam pembelajaran online, itu karena siswa tidak belajar cukup keras memperoleh skor sebesar 3,72 dan berkategorikan baik. Siswa yang kurang semangat dan mengalami kejenuhan dalam belajar terutama dalam matematika akan berdampak pada proses pembelajaran online dan siswa sulit untuk memahami materi yang diajarkan. Kendala proses belajar di masa pandemi adalah siswa kurang bersosialisasi dan berkomunikasi dengan teman sebayanya dan kedisiplinan siswa yang kurang dalam belajar.

Indikator selanjutnya yaitu persepsi siswa tentang tujuan orientasi intrinsik. Di dalam indikator ini memuat tiga pernyataan, yaitu 1) Di kegiatan pembelajaran matematika selama pandemi, siswa ingin memiliki beberapa referensi yang menantang dan membuat siswa belajar lebih banyak memiliki skor 3,55 berkategori baik, 2) siswa semangat mempelajari materi matematika yang dikreasikan dengan media online yang menarik memiliki skor 3,58 berkategori baik, dan 3) siswa harap guru memberi reward berupa poin saat pembelajaran online memiliki skor 3,98 berkategori baik. Dari ketiga pernyataan ini motivasi siswa dalam pembelajaran online terutama dalam matematika menginginkan ada referensi yang menantang, materi pembelajaran yang dikreasikan, dan guru memberi reward berupa poin kepada siswa yang aktif. Fasilitas maupun media yang diberikan guru kepada siswa seperti aplikasi WhatssApp dapat membantu guru dalam mengontrol kegiatan belajar siswa dan dapat memberikan tugas dengan berbagai macam format diantaranya dokumen, presentasi, foto maupun video(Yudianto, 2021)

Persepsi siswa tentang tujuan orientasi ekstrinsik memuat dua pernyataan, yaitu 1) setiap ada tugas online matematika, siswa tertantang untuk berdiskusi dengan teman melalui media memperoleh skor 3,78 berkategori baik. 2) pembelajaran online tidak sulit bagi siswa dan membuat pensaran untuk mempelajari materi lebih lanjut memperoleh skor 2,85 berkategori cukup. Siswa di dalam mempelajari materi lebih lanjut kurang setuju apabila dilakukan saat pandemi. Hal ini dikarenakan kondisi lingkungan dan keluarga yang kurang mendukung untuk bekonsentrasi dalam belajar. Anak yang menghadapi pelajaran dan kurikulum yang terlalu berat, justru menjadikan anak yang semula termotivasi untuk belajar menjadi kurang bersemangat. Keterlibatan orang tua dalam memberikan dukungan dan pemberian perhatian dalam tugas sekolah mampu memberikan kontribusi dalam peningkatan prestasi belajar (Fane \& Sugito, 2019).

Indikator berikutnya adalah nilai tugas. Nilai tugas memuat empat pernyataaan dalam motivasi belajar siswa, yaitu 1) keinginan terbesar pada siswa adalah mampu memahami isi materi pembelajaran yang disampaikan guru melalui media online memperoleh skor 4,15 berkategori sangat baik. 2) siswa kesulitan memastikan bahwa tugas yang dikirim melaui media telah sampai kepada guru memperoleh skor 3,55 berkategori baik. 3) jika siswa memperhatikan penuh saat pelajaran online, maka siswa bisa mendapatkan nilai yang lebih baik memperoleh skor 3,63 berkategori baik. 4) siswa kurang 
bersemangat dalam belajar apabila tugas yang sebelumnya tidak dikoreksi oleh guru memperoleh skor 3,75 berkategori baik. Dari keempat pernyataan, tertinggi memperoleh skor 4,15 yang berkategori sangat baik yaitu pernyataaan pertama bahwa keinginan terbesar siswa adalah mampu memahami isi materi pembelajaran yang disampaikan guru melalui media online. Siswa lebih bersemangat dalam belajar online apabila guru menunjang dengan aplikasi-aplikasi yang lebih kreatif. Guru juga harus mampu mengatasi siswa yang belum mahir pembelajaran online dengan mengeksplorasi teknologi digital seperti memperkenalkan dan mengintegrasikan saat pembelajaran online berlangsung (Putrawangsa \& Hasanah, 2018). Design pembelajaran yang dibuat menarik oleh guru akan meningkatkan konsentrasi siswa, selain itu antara siswa satu dengan yang lain dibuat berkolaborasi dalam memecahkan masalah. Hal ini dilakukan agar pembelajaran terutama matematika berjalan dengan efektif.

Kontrol kepercayaan untuk pembelajaran dalam tabel 2 memuat tiga pernyataan, yaitu 1) siswa dalam pembelajaran online berusaha mencari referensi lain untuk menambah pengetahuan memperoleh skor 3,92 berkategori baik. 2) siswa percaya akan meraih nilai matematika tinggi dengan mencari sumber pelajaran online yang lain memperoleh skor 3,5 berkategori baik. 3) siswa dalam mengikuti ujian online merasa ragu untuk menjawab pertanyaan memperoleh skor 3,68 berkategori baik. Hal ini dapat dilihat bahwa siswa belajar cukup keras untuk meraih nilai matematika tinggi dengan mencari referensi dan sumber pelajaran yang lain. Sebelum guru memberikan ujian secara online, siswa perlu diberikan arahan terutama dalam hal mental atau spiritual seperti berdoa sebelum ujian atau meminta ijin restu orang tua. Hal ini bisa mengurangi rasa ragu untuk menjawab pertanyaan. Berdoa maupun kegiatan spirirtual lain dapat menjadi salah satu usaha dalam mengurangi masalah yang dialami baik fisik maupun psikis (Oktawirawan, 2020).

Indikator yang terakhir adalah kecemasan saat tes. Dari tabel 2 kecemasan saat tes memuat empat pernyataan, yaitu 1) pelaksaan ujian secara online membuat siswa kurang berkonsentrasi sehingga takut kalau tidak berhasil dengan mendapatkan skor yang tinggi memperoleh skor 3,9 berkategori baik. 2) pembelajaran online matematika membuat siswa kurang memahami materi yang diajarkan sehingga takut tidak bisa menyelesaikan PR memperoleh skor 4,1 berkategori sangat baik. 3) kegiatan pembelajaran online matematika membuat siswa kurang berinisiatif dalam menanyakan kesulitan sehingga takut tidak bisa maksimal mendapatkan nilai yang lebih baik memperoleh skor 3,92 berkategori baik. 4) jika siswa tidak memperhatikan penuh apa yang disampaikan dalam pembelajaran online maka siswa khawatir tidak mendapatkan nilai yang tinggi memperoleh skor 4,02 berkategori sangat baik. Dari keempat pernyataan, ada dua pernyataan yang mendapatkan kategori sangat baik yaitu pernyataan kedua dengan skor 4,1 dan pernyataan keempat dengan skor 4,02. Dalam pembelajaran online terutama matematika guru biasanya memberikan tugas dan ujian kepada siswa, hal ini biasanya memberikan dampak rasa khawatir dan takut kepada siswa dikarenakan kurang memahami materi yang diajarkan dan kurang berinisiatif untuk menanyakan kesulitan kepada guru. Perasaan cemas, tegang, maupun 
takut yang dialami siswa dalam mengerjakan atau menghadapi ujian matematika dapat berpengaruh pada kemampuan pemecahan masalah matematika. Siswa yang mengalami kecemasan terhadap matematika merasa bahwa dirinya tidak mampu mempelajari matematika dan tidak bisa mengerjakan soal yang diberikan oleh guru (Fauziah \& Pujiastuti, 2020)

Berdasarkan uraian Tabel 2 didapatkan rata-rata enam indikator motivasi belajar siswa SMP dalam pembelajaran di era covid-19 diantaranya tujuan orientasi intrinsik, tujuan orientasi ekstrinsik, nilai tugas, kontrol kepercayaan dalam pembelajaran, kepercayaan diri, dan tingkat kecemasan adalah sebesar 3,71 yang berkategori baik, yang artinya siswa SMP Negeri 1 Grogol menunjukkan bahwa motivasi belajar dalam pembelajaran matematika di era covid-19 yang mengacu pada enam indikator yang sudah ditetapkan adalah baik.

\section{Pembahasan}

Motivasi belajar merupakan suatu dorongan dalam melakukan kegiatan belajar dalam rangka mencapai keberhasilan proses pada diri siswa untuk keberlangsungan dan penentuan arah pembelajaran. Motivasi belajar sangat mempengaruhi hasil belajar matematika. Siswa yang memiliki motivasi belajar yang tinggi mendapatkan hasil belajar matematika yang lebih baik dibandingkan dengan siswa yang memiliki motivasi belajar yang sedang dan rendah (Murtiyasa \& Al Karomah, 2020).

Berdasarkan dari data penelitian ini didapatkan indikator tujuan orientasi intrinsik adalah baik, yang berarti membuktikan bahwa kegiatan pembelajaran di era pandemi covid-19 siswa semangat dalam mempelajari matematika yang dikreasikan dengan media online yang menarik terutama dengan beberapa referensi yang menantang dalam belajar untuk lebih baik, serta siswa berharap guru memberi reward berupa poin saat pembelajaran. Siswa yang memiliki motivasi intrinsik akan memilih sesuatu yang dapat mengembangkan keterampilan baru yang ada pada dirinya dan melatih kreativitas (Dewi et al., 2019). Nuriski (2015) dalam penelitiannya menunjukkan adanya kontribusi positif dan signifikan motivasi belajar terhadap hasil belajar matematika dengan memperoleh persentase 19,09\% berkategorikan efektif dan terdapat kontribusi positif dan signifikan motivasi ekstrinsik terhadap hasil belajar matematika memperoleh persentase $24,91 \%$ berkategorikan efektif.

Indikator motivasi ekstrinsik dikategorikan baik, yang berarti membuktikan bahwa setiap ada pembelajaran online siswa tertantang untuk berdiskusi dengan teman melalui media. Indikator nilai tugas dikategorikan baik, yang berarti membuktikan bahwa siswa memiliki keinginan besar untuk memahami isi materi dari pembelajaran online dan kesulitan untuk memastikan apakah tugas yang dikirim telah sampai kepada guru, selain itu siswa bisa mendapatkan nilai yang lebih baik dengan memperhatikan penuh saat pelajaran dan kurang bersemangat apabila tugas yang sebelumnya tidak dikoreksi oleh guru. Bahwa guru yang tidak memberikan konsekuensi pada pengumpulan tugas maka hanya sebagian kecil siswa saja yang akan mengerjakan (Anita, 2014). Hal ini menjadi kebiasaan yang kurang baik pada siswa dalam proses belajar. 
Namun hal ini bisa dapat dikurangi dengan guru memberikan model metode belajar tertentu atau memberikan motivasi dalam memberikan tugas untuk mengerjakan dari yang lebih mudah.

Indikator kontrol kepercayaan untuk pembelajaran dikategorikan baik, yang berarti menunjukkan bahwa siswa dalam pembelajaran online percaya akan meraih nilai matematika tinggi dengan berusaha mencari referensi untuk menambah pemahaman. Akan tetapi, siswa juga ragu menjawab pertanyaan dalam mengikuti ujian matematika online. Indikator kepercayaan diri dikategorikan baik, yang artinya membuktikan bahwa siswa mengalami kesulitan saat mengerjakan tugas dengan waktu pengumpulan yang kurang serta siswa tidak belajar cukup keras dalam mempelajari materi sehingga tidak mampu memahami semua topik dalam pembelajaran. Hal ini berbeda dengan penelitian yang dilakukan Melinda dan Lazwardi (2020) yang menyatakan bahwa rata-rata percaya diri siswa dalam belajar matematika dinyatakan baik dengan persentase $67,32 \%$ diantaranya siswa setuju dalam mengikuti pembelajaran matematika dengan percaya diri meperoleh persentase $69,3 \%$, siswa setuju bahwa mereka percaya diri dalam menjawab soal yang dikerjakan memperoleh persentase $72,67 \%$, dan siswa cukup setuju bahwa mereka merasa pesimis dalam menyelesaikan permasalahan soal matematika memperoleh persentase $60 \%$.

Indikator kecemasan saat tes juga dikategorikan baik, yang artinya menunjukkan bahwa siswa kurang konsentrasi dalam pelaksanaan ujian secara online sehingga takut tidak berhasil meraih skor yang tinggi serta siswa takut tidak bisa menyelesaikan
PR karena kurang bisa memahami materi dengan tidak memperhatikan secara penuh saat pembelajaran berlangsung. Selain itu, kegiatan pembelajaran online membuat siswa kurang berinisiatif dalam menanyakan kesulitan dan takut tidak bisa maksimal mendapatkan nilai yang baik. Kecemasan yang dialami siswa dalam pembelajaran matematika ternyata bukan dari faktor kesulitan dalam memahami pelajaran, tetapi faktor lingkungan yang kurang memadai serta gangguan belajar yang sulit diprediksi dalam rumah (Nabilah et al., 2021)

Ditinjau dari beberapa uraian indikator motivasi belajar dalam pembelajaran matematika di era covid19 didapatkan rata-rata yang berkategori baik. Berdasarkan data analisis menunjukkan bahwa rata-rata tertinggi terdapat pada indikator kecemasan saat tes sedangkan rata-rata terendah terdapat pada indikator tujuan orientasi ekstrinsik. Analisis ini menunjukkan bahwa pembelajaran online bagi siswa tidak menimbulkan rasa penasaran untuk mempelajari materi lebih lanjut dikarenakan fasilitas media yang kurang mendukung. Fasilitas belajar diperlukan sebagai upaya peningkatan motivasi belajar. Dalam penelitian penggunaan media ICT berbasis for VBA Excel dapat mempengaruhi motivasi belajar siswa lebih meningkat (Romlah et al., 2019).

Penelitian ini menguatkan bahwa motivasi belajar siswa dalam pembelajaran daring memberikan pengaruh yang kuat bagi siswa dalam belajar matematika. Sejalan dengan penelitian (Murtiyasa \& Al Karomah, 2020) motivasi belajar memberikan pengaruh dalam hasil belajar matematika.

Kelebihan dalam penelitian ini diantaranya siswa merasa senang pelajaran online karena mudah mendapatkan 
sumber-sumber bacaan di internet dan dapat berkomunikasi dengan teman walaupun secara daring. Sejalan dengan penelitian (Nurhayati \& Purwanto, 2021) pembelajaran yang menggunakan zoom dan gmeet dapat membuat siswa belajar aktif, menjawab pertanyaan- pertanyaan, dan memahami pelajaran yang diberikan. Kekurangannya yaitu masalah teknis sinyal atau kehabisan kuota dan penggunaan media online seperti WhatsApp yang belum memaksimalkan guru dalam memberikan pembelajaran. Hambatan terbesar dalam penggunaan media diantaranya guru hanya berfokus pada pencapaian kurikulum.

Dalam penelitian ini bisa dijadikan referensi bagi guru dalam merencanakan dan melaksanakkan pembelajaran secara daring supaya siswa tetap mempunyai motivasi yang tinggi.

\section{KESIMPULAN DAN SARAN}

Penelitian ini menyimpulkan ratarata keseluruhan motivasi belajar siswa adalah berkategori baik. Hal ini dapat menunjukkan bahwa motivasi belajar siswa SMP Negeri 1 Grogol dalam pembelajaran matematika di era covid19 adalah baik. Di dalam penelitian ini motivasi belajar matematika memiliki beberapa indikator diantaranya tujuan orientasi intrinsik, tujuan orientasi ekstrinsik, nilai tugas, kontrol kepercayaan untuk pembelajaran, kepercayaan diri, dan kecemasan saat tes.. Indikator motivasi belajar yang sudah berkategori baik dapat ditingkatkan kembali sampai kepada berkategori sangat baik. Penelitian ini dapat digunakan sebagai dasar untuk merefleksikan deskripsi tentang motivasi belajar siswa terutama di masa pandemi covid-19. Selain itu dapat dijadikan sebagai referensi tentang motivasi belajar yang dialami siswa dengan situasi pembelajaran online.

Selanjutnya yang akan melakukan penelitian tentang motivasi belajar diharapkan dapat dilakukan bagaimana pengembangan media pembelajaran yang dapat membangkitkan motivasi belajar.

\section{DAFTAR PUSTAKA}

Anita, I. W. (2014). Pengaruh Kecemasan Matematika

(Mathematics Anxiety) Terhadap Kemampuan Koneksi Matematis Siswa Smp. Infinity Journal, 3(1), 125. https://doi.org/10.22460/ infinity.v3i1.43

Antakov, S. M. (2015). What is mathematics? Liberal Arts in Russia, $\quad$ 1(5), 358. https://doi.org/10.15643/libartrus2015.5.4

Arianti. (2018). Peranan Guru dalam Meningkatkan Motivasi Belajar Siswa. DIDAKTIKA: Jurnal Kependidikan, 12(2), 117-134.

Dewi, V. R., Syamsuri, S., \& Khaerunnisa, E. (2019). Karakteristik Motivasi Ekstrinsik dan Intrinsik Siswa SMP Dalam Belajar Matematika. TIRTAMATH: Jurnal Penelitian Dan Pengajaran Matematika, $\quad 1(2), \quad 116$. https://doi.org/10.48181/tirtamath. v1i2.7145

Et, A. L. W. (2017). Analisis Motivasi Belajar Pada Siswa Kelas. Gravity, 3(1), 90-99.

Fane, A., \& Sugito, S. (2019). Pengaruh keterlibatan orang tua, perilaku guru, dan motivasi belajar terhadap prestasi belajar matematika siswa. Jurnal Riset Pendidikan Matematika, 6(1), 53-61. https://doi.org/10.21831/jrpm.v6i1. 15246 
DOI: https://doi.org/10.24127/ajpm.v10i3.3711

Fauziah, N., \& Pujiastuti, H. (2020). Analisis Tingkat Kecemasan Siswa Dalam Menghadapi Ujian Matematika. Transformasi : Jurnal Pendidikan Matematika Dan Matematika, 4(1), 179-188. https://doi.org/10.36526/tr.v4i1.872

Mukuka, A., Shumba, O., \& Mulenga, H. M. (2021). Students' experiences with remote learning during the COVID-19 school closure: implications for mathematics education. Heliyon, 7(7), e07523. https://doi.org/10.1016/j.heliyon.202 1.e07523

Murtiyasa, B., \& Al Karomah, I. I. (2020). The impact of learning strategy of problem solving and discovery towards learning outcomes reviewed from students learning motivation. Universal Journal of Educational Research, 8(9), 4105-4112. https://doi.org/10.13189/ujer.2020.0 80936

Nabilah, E., Umam, K.,Azhar, E,.\& Purwanto, S., E (2021). Kecemasan Siswa Dalam Menyelesaikan Masalah Modelling Matematika Pada Praktek Kelas Virtual. International Journal of Progressive Mathematics Education. 1(1). 41-60

Nisa, L. K. N. (2021). Mewujudkan Motivasi Kemandirian Belajar Selama Penerapan Sistem Pembelajaran Online Era Covid-19. Jurnal Elementaria Edukasia, 4(1), 65-72. 10.31949/jee.v4i1.2885

Nurfajriyanti, I., \& Pradipta, T. R. (2021). Analisis Kemampuan Pemahaman Konsep Matematis pada Materi Bangun Ruang Sisi Datar Ditinjau dari Kepercayaan Diri Siswa. Jurnal Cendekia: Jurnal Pendidikan Matematika, 5(3), 2594-2603. https://doi.org/10.31004/cendekia.v5 i3.797

Nurhayati, F. E., \& Purwanto, S. E. (2021). Analysis of the Mathematics
Learning Motivation of Class XI IPA Students during the Covid-19 Pandemic. Edumatica: Jurnal Pendidikan Matematika, 11(01), 9398.

Oktawirawan, D. H. (2020). Faktor Pemicu Kecemasan Siswa dalam Melakukan Pembelajaran Daring di Masa Pandemi Covid-19. Jurnal Ilmiah Universitas Batanghari Jambi, 20(2), 541. https://doi.org/10.33087/jiubj.v20i2. 932

Putrawangsa, S., \& Hasanah, U. (2018). Integrasi Teknologi Digital Dalam Pembelajaran Di Era Industri 4.0. Jurnal Tatsqif, 16(1), 42-54. https://doi.org/10.20414/jtq.v16i1.20 3

Rismawati, M., \& Khairiati, E. (2020). Analisis Faktor Yang Mempengaruhi Rendahnya Motivasi Belajar Siswa Pada Mata Pelajaran Matematika. J-PiMat: Jurnal Pendidikan Matematika, 2(2), 203212. https://doi.org/10.31932/jpimat.v2i2.860

Romlah, S., Nugraha, N., \& Setiawan, W. (2019). Analisis Motivasi Belajar Siswa SD Albarokah 448 Bandung dengan Menggunakan Media ICT Berbasis For VBA Excel Pada Materi Garis Bilangan. Jurnal Cendekia: Jurnal Pendidikan Matematika, 3(1), 220-226. https://doi.org/10.31004/cendekia.v3 i1.98

Yudianto, M. B. (2021). Penggunaan Aplikasi Whatsapp untuk Pembelajaran. Jurnal Sosial dan Teknologi ( SOSTECH ), 1(8), 830839. 